\title{
De/Stabilizing Heterosexuality in the Pardoner's Tale
}

\author{
Mohamed Karim Dhouib \\ Faculty of Arts and Humanities of Sousse, Tunisia \\ kdhouib@yahoo.com
}

DOI: http://doi.org/ 10.36892/ijlls.v3i4.759

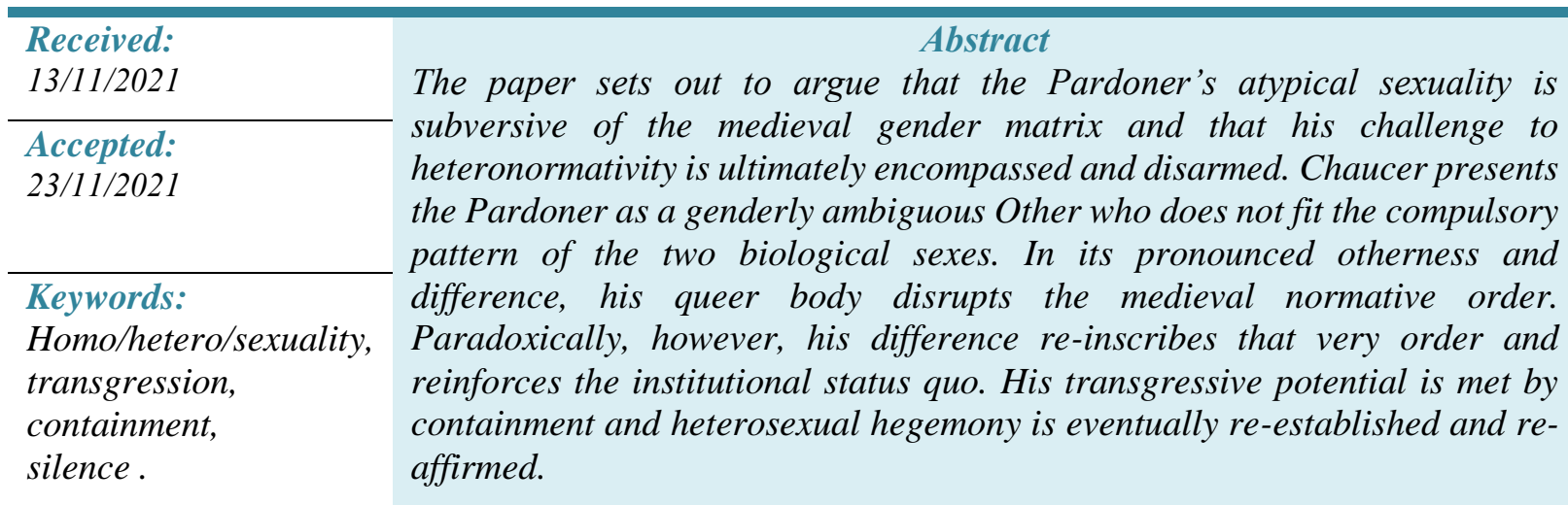

\section{INTRODUCTION}

Over the past six hundred years or so, critics have produced quite a significant body of works on the Pardoner's queer and perplexing gender and sexuality. In his 1919 essay "The Secret of Chaucer's Pardoner," Walter notes that the Pardoner "carries upon his body and has stamped upon his mind and character the marks of what is known to medieval physiognomists as a ennuchus ex nativitate," i.e., a man with no testicles (p. 597). Building on the views of the Greek physiognomist Polemon Laodicensis, Curry argues that the Pardoner is a born eunuch. Curry thus takes the Pardoner's "yelow," "smothe" hair (GP 675), "glarynge eyen" (GP 684), "small" voice (GP 688) and beardlessness to denote a blatant effeminacy, which he also connects to the manners of eunuchs. ${ }^{1}$

Miller (1955) concurs with Curry's pathologized reading of the Pardoner. His essay "Chaucer's Pardoner, the Scriptural Eunuch and The Pardoner's Tale" underlines the character's spiritual sterility. "As a type he is even more definitely evil," Miller comments (p. 198). The sin he typifies is presumption, peccatum in Spiritum Sanctum, for while "wilfully sinning against the Holy Ghost, he remains boastfully impenitent in full knowledge of his sin. Chaucer has produced a daring and effective irony in creating as his Pardoner the eunuch who presumptuously glories in the one unpardonable sin" (p. 193).

In her article "Animal Imagery and the Pardoner's Abnormalities," Rowland (1964) studies the dissonance in the Pardoner's gender traits and argues that the Pardoner is in fact androgynous. She calls him "a testicular pseudo-hermaphrodite of the feminine type" (p. 58). In his seminal book The Idea of the Canterbury Tales, Howard (1976) similarly reads the Pardoner a "feminoid" or a "hermaphroditic" male (p. 338) and a degenerate sexual deviant. He links the Pardoner's spiritual infertility to his sexual impotence. The Pardoner's false relics and sermons distance him from human and divine values. Alienated, he becomes a dislocated subject "on the periphery of the ordered world of created goodness," "marginal," "floating" and "demonic" (pp. 338-41). 
Much of the recent discussion of the Pardoner has turned around his confusing sexual identity. In her essay "The Pardoner's Homosexuality and How It Matters," McAlpine (1980) suggests that the Pardoner is "a possible homosexual" (p. 8) and that he is cast out by his "heterosexual and homophobic peers by a condition of homosexuality" (p. 10). McAlpine argues that Chaucer probes the inner consciousness of an ostracized and traumatized homosexual "despised by his society" (p. 16).

In Chaucer's Sexual Poetics, Dinshaw (1989) argues that "no one really knows what the Pardoner is" (p. 157). She finds that the Pardoner "obsessively desires wholeness, and wholeness is what he repeatedly claims his pardons will deliver" (p. 167). She explains that the Pardoner is mainly identified with absence/lack (male sexual organs and/or masculinity) and that to make up for this lack or sense of incompleteness he constructs a veneer of a preacher and fetishizes false relics which he markets for the duped people. His heterosexual comments are just a veil to cover up his true identity as a homosexual. The Pardoner, she says:

is not simply trying to enter into the heterosexual world of pilgrims; he is cannily playing on their desire to believe in integrity of the body - their desire to believe in the integrity of his body and the integrity of their own pilgrim body. (p. 180)

Similarly, Burger (2003) asserts in Chaucer's Queer Nation that the Pardoner's unintelligible body represents "a nexus of intermingling discourses about the subject and its meaning that cannot settle into a reassuring ordered hierarchy, but must work in conjunction, even in competition, in one another" (p. 141).

The principal target of concern in this paper is not to deflect the views of previous scholarship on the Pardoner and his tale but rather to fill in some of the gaps particularly in relation to the Pardoner as a sexually deviant Other who is yet contained by the mainstream sex/gender systems. The subversive Pardoner is outside the heterosexual matrix. He disrupts the hegemony of the binary frame, but is ultimately grotesqued, pathologized, silenced and cast out from the pilgrim community. His outsideness is already written in and managed by the overarching power network. A study like this one can surely be aided by the interpretive framework of Butler whose work on sexuality and gender might spell out some uncharted areas of the Pardoner's obscure gender identity and his tale.

\section{Theoretical Approach}

According to Butler, sex and gender are effects of a network of "compulsory heterosexuality" which monitors the identity of the subject (1993, p. 74). This network fabricates and naturalizes the categories man/woman and institutionalizes the oppression of non-normative subjects. Butler (1990) argues that:

The institution of a compulsory and naturalized heterosexuality requires and regulates gender as a binary relation in which the masculine term is differentiated from a feminine term, and this differentiation is accomplished through the practices of heterosexual desire. The act of differentiating the two oppositional moments of the binary results in a consolidation of each term, the respective internal coherence of sex, gender, and desire. (pp. 30-31)

Homosexual and other non-binary categories which do not follow the essentialized sex and/or gender assignments are denied recognition within the dominant binary heterosexual matrix. ${ }^{2}$ These peripheral or marginal subjects are discontinuous, incoherent and prohibited identities and therefore they disrupt compulsory and regulatory networks.

Butler believes that the regulation processes in these monitoring networks are reinforced through repetition, which sets and naturalizes gender categories. Like Foucault, Butler thinks that power represses, silences, and banishes. It represses both sexuality and discourse about sexuality. In Discipline and Punish (1975), Foucault explains how society produces a series of normalizing practices aimed at systematizing the economy of the body, 
and at fabricating compliant bodies acquiescent to hierarchical authority. These practices repetitively inscribe standards of normalcy on the body and sanctify fruitful or natural sexuality.

Repetition, however, opens up subversive potentialities, which present possibilities of destabilizing the matrix and the dominant configurations of gender. Butler believes that no matter how totalizing the effect of power is, there can always be subversion and reversal of the binary frame. Where there is power, there is subversion. And where there is normality, there is transgression dislocating it. The social order is a regularizing and policing network which nonetheless permits contravention of that network.

Butler thinks that there is an unremitting power-resistance, order-transgression dynamic and that these are overlapping networks in constant flux. She explains that "our acts are not self-generated, but conditioned. We are at once acted upon and acting, and our 'responsibility' lies in the juncture between the two" $(2004$, p.16). She speaks of the interventionist and repressive nature of the conventionalized and institutionalized gender and sexual patterns which concurrently make up/form and constrain/limit the subject. Sex, she says, is "forcibly materialized through time" in the "service of the consolidation of the heterosexual imperative" (1993, p. 1). The deep-seated and historically formed gender patterns enforce "compulsory heterosexuality" (1993, p. 74) and ensure the recuperation of transgression back into the normative order. For Butler, norms normalize, govern, and fashion subjects. In a profoundly Foucauldian tone, Butler comments: "If we defy these norms it is unclear whether we are still living" (2004, p. 206).

To sum up, the social order is a regularizing matrix of processes which is at once (1) open to transgression and resignification and (2) repressive or coercive. The gender matrix permits intervals of subversion and disruption but neutralizes or defuses deviations. The subject is as much an actor as an acted upon. "Perhaps it is a repeated predicament: to be given over to a world in which one is formed even as one acts or seeks to bring something new into being," Butler admits in her Precarious Life (2004, p. 16). The subject's existential predicament is to continually be an operator of power and operated by the same power. It is within similar lines of analysis that the Pardoner and his tale shall be scrutinized.

\section{Medieval Homosexuality}

Homosexuality in Chaucer's time is an inexcusable and "unpardonable" gender irregularity (Sturges, 2000, p. 55). ${ }^{3}$ It is an act discordant with the general laws of nature as it does not serve the natural function of procreation. It is categorized as nefandum, the unspeakable. William Peraldus (a twelfth-century Dominican preacher), for example, voiced the Pauline prohibitions: "this vice is to be spoken of with great caution both in preaching and in confessional questioning, that nothing be revealed to men that might give them occasion to sin" (qtd. in Jordan, 1997, p. 31). In the words of Chaucer's Parson, homosexuality is "thilke abhomynable synne, of which that no man unnethe oghte speke ne write" (PT 909). Homosexuality is the unnamed and unnameable sin.

The Bible plainly condemns homosexuality and hails it as shameful, unnatural, perverse, detestable, and immoral:

ROMANS 1:26-27

Because of this, God gave them over to shameful lusts. Even their women exchanged natural relations for unnatural ones. In the same way the men also abandoned natural relations with women and were inflamed with lust for one another. Men committed indecent acts with other men, and received in themselves the due penalty for their perversion.

LEVITICUS 18:22

Do not lie with a man as one lies with a woman; that is detestable.

1 CORINTHIANS 6:9-10 
Do you not know that the wicked will not inherit the kingdom of God? Do not be deceived: Neither the sexually immoral nor idolaters nor adulterers nor male prostitutes nor homosexual offenders nor thieves nor the greedy nor drunkards nor slanderers nor swindlers will inherit the kingdom of God.

St. Augustine also speaks about homosexuality as contra natrura in his Confessions and The City of God. As he sees the goodness of sexual intercourse only if it is directed to its proper natural purpose (procreation), same-sex behavior becomes unacceptable because it lacks such a purpose. In the Confessions, he says that sodomy is an unnatural, detestable and punishable act:

Therefore shameful acts which are contrary to nature, such as the acts of the Sodomites (Gen 19: 5), are everywhere and always to be detested and punished. Even if all peoples should do them, they would be liable to the same condemnation by divine law, for it has not made men to use one another in this way. Indeed the social bond which should exist between God and us is violated when the nature of which he is the author is polluted by a perversion of sexual desire. (46)

In similar vein, Aquinas (1947) sharply condemns homosexual conduct. In his Summae Theologica, he writes:

a special kind of deformity whereby the venereal act is rendered unbecoming ... may occur in two ways: First, through being contrary to right reason, and this is common to all lustful vices; secondly, because, in addition, it is contrary to the natural order of the venereal act as becoming to the human race: and this is called the unnatural vice ... [i.e.] copulation with an undue sex, male with male, or female with female... and this is called the vice of sodomy. (p. 2438)

For Aquinas, the homosexual conduct is "contrary to the natural order of the venereal act" as well as "contrary to right reason." He adds:

since by the unnatural vices [which he earlier identified as masturbation, bestiality, homosexual copulation, and what might be called heterosexual sodomy] man transgresses that which has been determined by nature with regard to the use of venereal actions, it follows that in this matter this sin is gravest of all. (p. 2438)

In De Lille's(1980) Plaint of Nature, a twelfth-century philosophical work to which Chaucer refers in his Parliament of Fowls (p. 316), homosexuality is also explained in terms of perversion and distortion of nature's normal course:

The sex of active nature trembles shamefully at the way in which it declines into passive nature. Man is made woman, he blackens the honor of his sex, the craft of magic Venus makes him of double gender. He is both predicate and subject, he becomes likewise of two declensions, he pushes the laws of grammar too far. He, though made by Nature's skill, barbarously denies that he is a man. [...]

Art does not please him, but rather artifice; even that artificiality cannot be called metaphor; rather it sinks into viciousness. He is too fond of logic, with whom a simple conversion causes the rights of Nature to perish. He strikes on an anvil which emits no sparks. The very hammer deforms its own anvil. The spirit of the womb imprints no seal on matter, but rather the plowshare plows along a sterile beach. (pp. 67-69)

The unproductiveness and sterility of the homosexual act is described in linguistic terms. The breach of the normal course of sexuality is analogous to the abuse of the codes of language and the laws of grammar.

\section{The Pardoner in the General Prologue}


The Pardoner is the last of the pilgrims to be described in the General Prologue, a curious position which not only denotes a condition of otherness and eccentricity but also casts a cloud of suspicion over his morality. The first mention of the Pardoner already problematizes his sexual orientation and suggests the possibility of a non-binary subject:
With hym ther rood a gentil Prdoner
Of Rouncivale, his freend and his compeer,
That straight was comen fro the court of Rome.
Ful loude he soong "Com hider, love, to me!"
This Somonour bar to hym a stif burdoun; [strong bass / large penis]
Was nevere trompe of half so greet a soun. (GP 672-77)

The auditory image is of the Pardoner merrily singing a duet with another clergyman, the Summoner. The Pardoner's high feminine voice and the Summoner's masculine bass might imply a possible homosexual partnership between the two compeers. ${ }^{4}$ While the medieval translation of the "stif burdoun" refers to the Summoner supplying the bass vocals to the Pardoner's song, the same expression could carry phallic overtones. Sturges (2000) points that "the pun on the Summoner's musical and erotic 'stif burdoun,' with its hints of anal penetration, brings the Pardoner's song to an even more fundamentally bodily level" (p. 98). Medieval readers, he says, would not miss the hint at the Pardoner's (passive) homosexuality.

The description then turns visual with an elaborate sketch of the Pardoner's queer body and his fetishistic objects:
This pardoner hadde heer as yellow as wex,
But smothe it heng, as dooth a strike of flex;
By ounces henge his lokkes that he hadde,
And the therwith he his shuldres overspradde;
But thinne it lay, but colopons oon and oon;
But hood, for jolitee, wheret he noon,
For it was trussed up in his walet.
Him thoughte he rood al of the newe jet;
Dischevele, save is cappe, he rood al bare.
Swiche glaringe eyen hadde he as an hare.
A vernicle hadde he sowed on his cappe.
His walet lay biforn him in his lape,
Bretful of pardoun comen from Rome al hoot.
Avoys he hadde as smal as hath a goot.
No berd hadde he, ne never sholde have,
As smothe it was as it were late shave:
I trowe he were a gelding or a mare. (GP 675-91)

The Pardoner's flaxen hair hanging over his shoulders, his glaring and hare-like eyes, his small goat-like voice and beardless face powerfully build up a picture of a subject whose sexuality does not map onto the orthodox sexual trajectories. He is in Butler's terms, an "incoherent or discontinuous gendered being who fail[s] to conform to the gendered norms of cultural intelligibility by which persons are defined" (1990, p. 23). The wallet or bag of pardons on his lap perhaps covers the lacking sexual organs. The Pardoner's portrait is sealed up with the narrator's infamous statement "I trowe he were a geldying or a mare" (GP 691) which raises more questions as to his sexual deviancy. Is he a gelding (a castrated horse) or a mare (a female horse)? Is he a castrate or a female-bodied person? Is he homosexual? Is he bisexual? Regardless of what type of gender identity he has, the idea that something is missing from the Pardoner is unmistakable. Either way, the Pardoner lacks physical indication of masculinity and seems to be burdened with a sex assignment that does not fit within the binary framework. 


\section{The Subversive Pardoner and his Tale}

According to Butler, subverting the matrix of gender norms and displacing its naturalized and reified patterns is always possible (1990, p. 44). No matter how insidious and pervasive the power grid is, there can always be a prospect of undoing these deep-rooted patterns and norms. Where there is regularity/uniformity, there is deviation/digression. The subject could unsettle and disrupt the mainstream heteronormative structures and inscribe his/her otherness. The gender matrix is a totalizing network which nevertheless allows for subversion of that network.

The Pardoner re-inscribes his difference along new lines and deconstructs the narrator's scarring condemnation of his body. In his own prologue to his tale, the Pardoner, a master orator and exhibitionist, undermines the way he is portrayed in the General Prologue and defiantly foregrounds his stigmatized body as an impetus for subversive inversion and an instrument serving his religious chicanery. He reconstructs himself and makes of his wounds discursive scars:

I peyne me to han an hauteyn speche, [loud voice]

And rynge it out as round as gooth a belle. (PardT 330-31, emphasis added)

While the narrator pejoratively talks about the Pardoner's small and goat-like voice as indicative of his effeminacy, the Pardoner proudly talks about the resonance and wonder of his voice. He makes of it a potent signifier of his power. His voice, he says, rings out as goes a church bell. It gives him a sense of completeness and wholeness.

With his agile tongue, the Pardoner orchestrates the performance of the tale and turns the scene to a theatrical show in which his grotesqued body would take the limelight. Kruger (1994) finds that "[n]one of the other male pilgrims, and only the Wife of Bath among the women, describes him- or herself in such strongly physical terms, and as so clearly the object of the public gaze" (p. 132). In fact, the Pardoner is a preacher-actor and a skilled performer who seeks to manipulate his audience and make them buy his false relics even though they know he is sexually odd and morally dubious. As Dinshaw (1989) suggests:

He is exploiting their fetishistic ability to admire his oddity even while they refuse the practical consequences of their admission. They know (that he is sexually weird) but even so (they demand a 'moral thyng' from him). (p. 180)

While the Pardoner's body surely denotes gender ambiguity, this ambiguity represents an interval for transgression. It is a subversive confusion that creates "gender trouble" in the dominant categories which seek to keep gender in its place (Butler, 1990, p. 44). The Pardoner knowingly manoeuvres his own ambiguous body as a reconfigurable entity to resignify his gender identity and serve his purposes. He is both male and female and operates "outside the norms of binary division" (DeVun, 2008, p. 194). His physical weirdness disrupts the regulatory gender networks and empowers his deviation from normalcy.

Zeikowitz (2002) states that "despite uncertainty of what, if anything, is between his legs, the Pardoner wields enormous power of speech" (p. 61). The narrator himself recognizes the Pardoner's great oratorical skills: "Upon a day he gat hym moore moneye / Than that person gat in monthes tweye" (GP 705-06). His voice might well be goat-like but certainly not weak or languid. He uses it most effectively in church where he "song an offertorie ... muriedly and loude" $(G P 710,714)$ to "wynne silver" GP 713). His toolkit comprises a nimble tongue, some relics and a bag of stories and exempla.

The Pardoner uses words to get money from the gullible people. He keeps his weapon, his tongue, geared up to manoeuvre his audience:

Of avarice and of swich cursednesse

Is al my prechyng, for to make hem free 
To yeven hir pens, and namely unto me.

For myn entente is nat but for to wynne,

And nothyng for correccioun of synne. (PardT 400-404)

He arrogantly confesses that preaching is a sort of cover-up for him to maximize profit. Howard (1976) points that the Pardoner's "capacity for dominating others" is sadistically incomparable. The Pardoner has a grasping craving for control which is driven by an "avowed1y rapacious motive." His theatrical powers include the ability to see both his audience's repulsion and absorption by his matchless, even mystifying spirit. Taking advantage of his hypnotizing oratorical powers, the Pardoner attempts to be flattering in order to trick the pilgrims into buying his false relics. Howard connects the bestial picture of the Pardoner (as a goat, a hare and a mare) with his ravenous motive in telling his "sermon" which amounts to a "monstrous verbal rape" (p. 347).

Equally expressive of the Pardoner's verbal virility is the conclusion of his prologue where he boldly boasts:

\author{
I wol noon of the apostles countrefete; [I will have] \\ I wol have moneie, wolle, chese, and whete, \\ 1 were it yeven of the povereste page, \\ Or of the povereste wydwe in a village, \\ 1 sholde hir children sterve for famine. \\ Nay, I wol drynke licour of the vyne \\ And have a joly wenche in every toun. (PardT 447-53)
}

The repetition of "I wol" here does not suggest "an enormous lack, an unquenchable cupiditas" as Dinshaw (1989) suggests (p. 162). Nor does it suggest a heterosexual masquerade meant to impress his audience. It is rather an expression of self-assertion from a differently gendered transgressor. Howard (1976) aptly observes that "the Pardoner wills the role he plays [and] in rejecting the prescribed role-model and playing himself, he decides against the world" (p. 374). He imposes his gender difference on the other pilgrims or in the words of Zeikowitz (2002), he "thrusts his otherness on their faces" (p. 64) and unsettles the normative gender matrix.

It is accordingly not surprising that the Pardoner is the only pilgrim to flout the directives of the authoritative and imposing Host. The Host commands the Pardoner to tell "som myrthe or japes right anon" to tone down the lingering bleakness of the Physician's dreadful tale (PardT 319). The Pardoner does the opposite and delivers not "ribaudye" (PardT 324) but "som moral thyng, that we may leere / Som wit" (PardT 325-26). He satisfies his audience's desire and totally ignores the Host. ${ }^{5}$

The tale is, in fact, an extension to the Pardoner's melodramatic show. Like present day televangelists, the Pardoner tells a poignant and heart-rending tale to stage-manage the audience and call for funds. This explains why the tale is spiritually correct even though the teller is far from being spiritual. "His tale," says Gregory Gross (1995), "is told as yet another example of the tricks of his trade, not as an exemplum to be taken in earnest" (p. 5). It is yet another ploy in the storyteller's pocket, un outil de travail serving his business.

The tale is about three revellers heavily drinking in a tavern when they "herde a belle clynke/ Biforn a cors, was caried to his grave" (PardT 364-65). They learn that an old friend died at the hands of a "prive theef" named Death $(\operatorname{PardT} 675) .{ }^{7}$ Enraged, the three rioters swear to kill Death. On their way to seek Death and slay him, they meet a strange old man who tells them that Death can be found under an oak tree. When they get there, what they find is not Death but a fabulous treasure, a heap of "floryns fyne of gold" (PardT 770). The youngest is sent to town to get some bread and wine. The other two plot to kill him when he comes back. Conquered by gluttony, the youngest puts rat poison in the wine to slay his two fellows and get the all the gold for himself. On his return, he is attacked and stabbed to death. After celebrating 
with a drink, the two murderers meet their deaths by the poison. The three sworn questers die because of their rapacious and insatiable cupidity.

The plain lesson in the Pardoner's homily is: Radix malorum est Cupiditas, i.e., greed is the root of all evil (PardT 334). The radix malorum in the tale is definitely money. Without money, the mutinous fellows would not engage in gambling, sex and wine (PardT 465). When "Thise riotoures thre" (PardT 661) find the "eighte busshels" of gold (PardT 771), they are overwhelmed with gluttony: "In myrthe and joliftee oure lyfe to lyven" (PardT 780). The avid greed for money kills the three of them. The Pardoner's argument is so well crafted and orchestrated in the narrative: money leads to intemperance and eventually death. As the story draws to its ending, the Pardoner gives a long list of deadly sins and rhetorically and theatrically sets the stage for his ultimate aim:

O cursed synne of alle cursednesse!

O traytours homycide, $\mathrm{O}$ wikkednesse!

O glotonye, luxurie, and hasardrye!

Thou blasphemour of Crist with vileynye

And othes grete, of usage and of pride! (PardT 895-99)

He gets back to the tale's core dictum (greed is the root of all evil) and proceeds to trick his audience into buying his hooly pardouns:

\author{
Now, goode men, God foryeve yow youre trespas, \\ And ware yow fro the synne of avarice! \\ Myn hooly pardoun may yow alle warice, \\ So that ye offre nobles of sterlynges, \\ Or elles silver broches, spoones, rynges. \\ Boweth youre heed under this hooly bulle! \\ Cometh up, ye wyves, offreth of youre wolle! (PardT 904-10)
}

As David (1976) puts it, "the logical conclusion to be drawn is that if anyone is carrying Death in his pockets, he should give it to the Pardoner" (p. 201). In the Pardoner's self-serving semantics, death is a metonymy for money.

The Pardoner dislocates the regulatory fiction of heterosexual coherence and disrupts the very borders of gender identity. In fact, he locates himself within a third-gender position that subverts the hegemonic conceptual scheme and that offers "an experience beyond the [set] categories," to quote Butler (1990, p. 162). He transforms his otherness into a source of power that goes beyond the binary frame and that destabilizes the dominant configurations of gender. His fluidity re-signifies gender and helps him act out his performance/s in front of his audience and get what he wants: selling as many pardons as possible.

\title{
6. The Silenced Pardoner
}

As noted earlier, subversion is always met by containment. Like Foucault, Butler believes that power silences and suppresses subversive potentialities. The social network manages and controls the economy of the body through standardized and regimented norms and practices which aim at regulating sexuality and keeping up the current order. These norms and practices corroborate principles of normalcy and authorize the terms of ab/normal sexuality. The network operates through various institutions and discourses to produce manageable and acquiescent bodies and re-affirm heteronormative hegemony. Foucault (1978) notes in Volume I of The History of Sexuality that:

[w]here there is power, there is resistance, and yet, or rather consequently, this resistance is never in a position of exteriority in relation to power. Should it be said that one is always 
"inside" power, there is no "escaping" it, there is no absolute outside where it is concerned, because one is subject to the law in any case? (p. 95)

Subversion is already embedded within the processes of power and cannot get to a position of exteriority in relation to those processes. The subject's self-invention is always acted out in the existing social and cultural norms and is geared or accommodated by the dominant structures of power.

The Pardoner's disruption of the binary frame is given a voice only to be quickly undone and contained. In fact, the trancelike and allegorical quality of the Pardoner's exemplum is promptly subverted by the violent clash with the Host, the masculine moderator of the tale-telling contest and the model of heteronormativity in the community of pilgrims. In the General Prologue, the Host is described in a language that powerfully evokes his virility and manliness:
A seemly man our Hooste was withalle
For to been a marchal in an halle.
A large man he was with eyen stepe,
A fairer burgeys was there noon in Chepe-
Boold of his speche, and wys and wel ytaughte,
And eke of manhood hym lakkede right naught.
Eek therto he was a myrie man. (GP 751-57, italics mine)

Unlike the physically "unmanly" sketch of the Pardoner, the Host's portrait is given in terms that emphatically express his hyper-masculinity. The Host's commanding "eyen stepe" contrast sharply with the Pardoner's effeminate "glarynge eyen" (GP 684). The Host's "boold speche" also stands loudly against the Pardoner's goat-like voice (GP 688). The term "marchal" cogently associates the Host with knighthood, courtliness and perhaps even chivalry. Besides, the identification of the Host's vocation as a tradesman, a "burgeys," underlines his integrity and honourableness and calls to mind the Pardoner's fraudulence and duplicity.

The provocative Pardoner accuses the Host of being the most sinful of all the pilgrims and farcically invites him to open up his purse and get some coins to pay for the kissing of his holy relics:

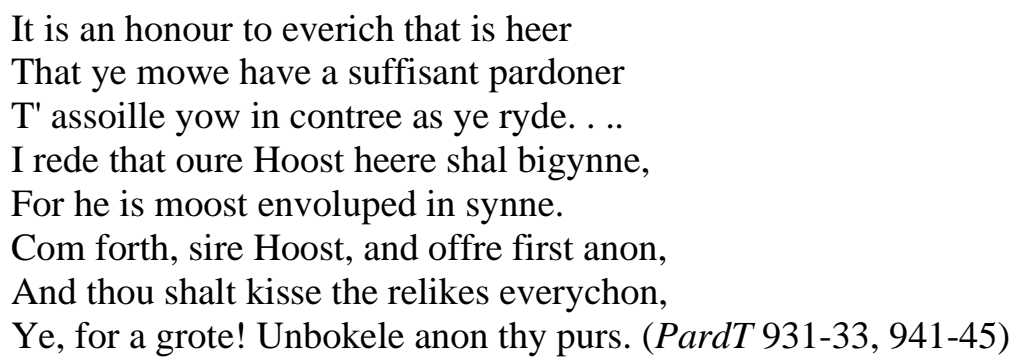

The furious Host "performs the judging function with an anger which expresses the view of conservative society towards this Pardoner and his threat" (Knight, 1986, pp. 130-31). He angrily threatens to have the Pardoner's testicles (his masculinity) exposed, cut off and sanctified in a hog's turd (excrement):

I wolde I hadde thy coillons in myn hond

In stide of relikes or of seintuarie.

Lat kutte hem of, I wol thee helpe hem carie;

They shul be shryned in an hogges toord! (PardT 952-55). 
The castration threat redirects the audience to the Pardoner's amorality and atypical gender and sexuality. The Host, "who acts as the voice of normative judgment" (Knight, 1986, p. 131), exposes the Pardoner's deceptive trading in false relics and his possible homosexuality and/or eunuchry. He deconstructs what the Pardoner has been trying to reconstruct and opens up his wounds again.

Gross (1996) analyzes the castration scene in terms of the Pardoner's sexual and spiritual barrenness. He comments that the Pardoner's "sodomitic appetite is just as base [as excrement], a repugnant corruption of authentic fruitful sexual behaviour" (pp. 21-22). His fake relics, just like his testicles (if he has any), produce nothing. More significantly, the Host deprives him of a more real attribute than his testicles, his most cherished tool: his speech:

This Pardoner answered nat a word;

So wroothhe was, no word ne wolde he seye. (PardT 956-57, emphasis added)

The untesticled Pardoner is untongued and does not utter a word after this clash. In so doing, the Host "reclaims a specifically masculine authority that has been threatened" by abnormalcy (Sturges, 2000, p. 6). He rhetorically subdues and suppresses the gendered digression enacted by the Pardoner. The Pardoner, so to speak, is "verbally dismembered" (Sturges, 2000, p. 6), muted and stamped out.

The Knight, another emblematic figure of heternormativity, steps in to stabilize the disrupted gender matrix and bolster the institutional status quo. ${ }^{8}$ He sets up the silencing and expurgation of the subversive Pardoner:

But right anon the worthy Knyght bigan,

Whan that he saugh that al the peple Iough,

Namoore of this, for it is right ynough!

Sire Pardoner, be glad and myrie of cheere;

And ye, sire Hoost, that been to me so deere,

I prey yow that ye kisse the Pardoner.

And Pardoner, I prey thee, drawe thee neer,

And, as we diden, !at us laughe and pleye.

Anon they kiste, and ryden forth hir weye. (PardT 960-68)

The primary incentive of the Knight (as an agent of containment) is not to heal the resentment that has flared up or reintegrate the publically shamed Pardoner within the community of pilgrims. It is rather to stifle the Pardoner's "hauteyn speche" (PardT 330) and restore the patriarchal gender hierarchy. The Knight gently asks the Host and Pardoner to kiss and resume the tale-telling game. The kiss does not so much appease the Pardoner's shame. It rather deepens his sense of expulsion and heralds his narrative death. He is perpetually written off. Wetherbee (2004) states that:

[t]his conclusion to the Pardoner's performance, reducing him to traumatic silence and so rendering him impotent in a new way, leaves us with the question of just what resolution the story of such a man could have. The Pardoner seems cut off from any social function save the power his negative example and self-denying eloquence may exert in the lives of others. (p. 72)

The narrator's pejoratively pathologized portrait of the Pardoner, the Host's castration threat, and the Knight's kiss verdict work together to lock up and contain the Pardoner's deviancy and congeal the tale's conservatism.

In thus ending the tale, Chaucer restores the rigid codes of hierarchical binarisms which govern the world of the Canterbury Tales. He re-inscribes the "reassuring binaries: impotent Pardoner/virile Host, sterile Pardoner/vigorous "gentils," morally bankrupt Pardoner/ spiritually worthy Knight" (Burger, 2003, p. 141). The tale, to use a Butleresque formulation, 
reinforces "the binary, heterosexist framework that carves up genders into masculine and feminine and forecloses an adequate description of the kinds of subversive and parodic convergences that characterize gay culture" (1990, pp. 84-85). It reinstates the coherent configurations of gender/sex imposed by the heterosexual matrix and reasserts the regulatory binary frame.

Gross (1996) comments that Chaucer is not "a progressive voice in the oppressive Middle Ages, [dedicated] to a liberal politics of "diversity" [..] including a "gay man" in the company of Canterbury pilgrims" (p. 31). The Pardoner is given a place in the Canterbury Tales only to be obscured, disowned and pushed to the margin. In similar vein, Howard (1976) cogently writes that "medieval art had a place for the grotesque, but it was never at the center of things - it was on the outside or the underside" (p. 338). The deviant can always subvert or reverse the effects of power but cannot go beyond his alterity and break with its context.

Chaucer, in fact, subscribes to an essentialist view of sexuality. While critical of many aspects of the socio-gender structures of his day, he embraces a mainstream vision of the heteronormative matrix with its strict identity categories. He is "politically conservative in his representations of difference," in the words of Robertson (2003, p. 323). In its silencing of the subversive and genderly ambiguous Pardoner, the text offers a conservative defence of traditional gender categories. The essentialized sex/gender system finally subsumes non-binary categories and reproduces the hegemony of the institutionalized norms and regularizing patterns.

The atypical Pardoner, the exclusively male cast of his tale (the three revellers and the strange old man), the tale's macabre backdrop (a desolate oak tree in a plagued land), and the story's own self-destruction (the three rioters die in their tragic quest) epitomize the sterility, infertility and disintegration ascribed to his homosexual identity. His bizarre sexuality, like the plagued and death-ridden landscape of the tale, produces nothing but barrenness, an image that brings to mind the "ploughing along a sterile beach" in de Lille's Plaint of Nature (p. 69). Similarly, his preaching, because it does not serve its natural function of producing spiritual benefit, is unfulfilling and fruitless. It is just empty rhetoric. Inverted gender, just like false preaching, is presented as "a vicium, a defect" (Gross, 1996, p. 28). In his own words, the Pardoner is "a ful vicious man" (PardT 459, italics mine), a decadent trickster whose only intent is to market his forged wares to the poor people. Silence is the final verdict for his sexual abnormalcy and spiritual degeneracy.

\section{CONCLUSION}

The Pardoner is perhaps the first angry atypically gendered character in English literature. He is different and is therefore a menace to heteronormative patriarchal structures. His physical and spiritual dissonance along with his linguistic potency as dramatized in his prologue and tale are met by a set of multiple containments which operate concurrently against his subversive potential. The Host's castration threat and the Knight's coup de grace kiss announce the erasure and invalidation of the Pardoner and what he stands for. The Pardoner's alterity is eventually suppressed and heterosexual hegemony is restored. Like many other forces of disruption in the Canterbury Tales, the Pardoner's gender atypicality is raised only to be osrtacized and wiped out.

\section{NOTES}

1) This and all subsequent references to the Canterbury Tales are taken from F. N. Robinson's The Complete Works of Geoffrey Chaucer (1957). The tales referred to in the article are abbreviated as follows: GP for the General Prologue, PardT for the Pardoner's Tale, and PT for the Parson's Tale.

2) Butler (1990) defines the term heterosexual matrix as "the grid of cultural intelligibility through which bodies, genders, and desires are naturalized" (p. 193). It is a hegemonic 
"discursive/epistemic model of gender [...] that is hierarchically defined through the compulsory practice of heterosexuality" (p. 193).

3) It should be pointed out that while the concepts sodomy and homosexuality refer to two different categories pertaining to two different cultures, they do refer to a similar conceptualization of same-sex relations. As Burger (2003) puts it in his book Chaucer's Queer Nation, "there are analogies between medieval sodomite and modern homosexual as subject categories constituted as negatives by dominant culture" ( $\mathrm{p}$. 126).

4) The Summoner is described as a villainous old man in the General Prologue. He makes illicit deals with people to gain money. He is a sexual predator of "yonge girls" (GP 664). He pretends to speak Latin but only parrots a few words (GP 638). The Pardoner and the Summoner, two church officials, are ironically drinking and singing a carnal or perhaps erotic (rather than spiritual) song of love.

5) This is powerfully reminiscent of the Miller's disruption of the Host's stabilizing plans for the Canterbury tale-telling game. Like the Miller, the Pardoner usurps the authority of the Host and sets his own terms in the tale contest.

6) Many critics see that the teller and tale are unmatched given the Pardoner's pronounced hypocrisy, religious trumpery and moral bankruptcy. Kittredge (1959), for instance, says that Chaucer "has grossly violated dramatic propriety" in failing to make the Pardoner's epilogue in tune with the tale he tells (p. 117).

7) The "prive theef" is nothing but the Black Death, a highly contagious bubonic disease which, in its erratic outbreaks in Chaucer's day, reduced England's population by almost a half (Hays, 1998, p. 58).

8) The Knight's intervention in the Host-Pardoner quarrel, perhaps the most violent disruption on the way to Canterbury, is reminiscent of King Theseus's peacemaking efforts in the Knight's Tale. Both strive to restore order and promptly encompass any dissident potentialities that might threaten the set norms and institutionalized standards.

\section{REFERENCES}

De Lille A. (1980). De Planctu Naturae. (James J. Sheridan, Trans.). Pontifical Institute of Medieval Studies.

Aquinas, T. (1947). Summa theological (Fathers of the English Dominican Province, Trans.). Benziger Bros.

Augustine. (1991). Confessions (Henry Chadwick, Trans.). Oxford University Press.

Burger, G. (2003). Chaucer's queer nation. University of Minnesota Press.

Butler, J. (1990). Gender trouble: feminism and the subversion of identity. Routledge.

Butler, J. (1993). Bodies that matter: On the discursive limits of "sex." Routledge.

Butler, J. (2004). Precarious life: the powers of mourning and violence. London: Verso.

Butler, J. (2004). Undoing gender. Routledge.

Chaucer, Geoffrey. (1957). The works of Geoffrey Chaucer (F. N. Robinson, ED). Houghton Mifflin.

Curry, W. C. (1919). The secret of Chaucer's Pardoner. Journal of English and Germanic Philology, 18, 593-606.

David, A.. (1976). The strumpet muse: art and morals in Chaucer's poetry. Indiana University Press.

DeVun, L. (2008). The Jesus hermaphrodite: science and sex difference in premodern Europe. Journal of the History of Ideas, 69(2), 193-218.

Dinshaw, C. (1989). Chaucer's sexual poetics. Wisconsin University Press.

Foucault, M. (1975). Discipline and punish. (Alan Sheridan, Trans.). Vintage Books.

Foucault, M. (1978). The history of sexuality. (Robert hurley, Trans.). Pantheon Books.

Gross, G. W. (1996). Trade secrets: Chaucer, the Pardoner, the critics. Modern Language Studies, 25(4), 1-36. 
Hays, J. N. (1998). The burdens of disease: Epidemics and human response in Western history. Rutgers University Press.

Holy Bible (1999). Cambridge University Press.

Howard, D. (1976). The idea of the Canterbury Tales. University of California Press.

Jordan, M. D. (1997). Homosexuality, luxuria, and textual abuse. In Karma Lochrie, Peggy McCracken, and James A. Schultz (Eds.), Constructing medieval sexuality (pp. 34-59). University of Minnesota Press.

Kittredge, G. L. (1959). Chaucer's Pardoner. In Edward Wagenknecht (Ed.), Chaucer: Modern essays in criticism (pp. 117-25). Oxford University Press.

Knight, S. (1986). Geoffrey Chaucer. Basil Blackwell.

Kruger, S. F. (1994). Claiming the Pardoner: Toward a gay reading of Chaucer's Pardoner's Tale. Exemplaria, 6(1), 115-39.

McAlpine, M. (1980). The Pardoner's homosexuality and how it matters. PMLA, (95)1, 8-22.

Miller, R. P. (1955). Chaucer's Pardoner, the scriptural eunuch, and The Pardoner's Tale. Speculum 30(2), 180-199.

Robertson, E. (2003). Nonviolent Christianity and the strangeness of female power in Geoffrey Chaucer's Man of Law's Tale. In Sharon Farmer and Carol Pasternack (Eds.), Gender and difference in the Middle Ages (pp. 322-53). University of Minnesota Press.

Rowland, B. (1964). Animal imagery and the Pardoner's abnormality. Neophilologus 48(1), 56-60.

Sturges, R. S. (2000). Chaucer's Pardoner and gender theory: Bodies of discourse. MacMillan. Wetherbee, W. (2004). Geoffrey Chaucer: The Canterbury Tales. Cambridge University Press. Zeikowitz, R. E. (2002). Silenced but not stifled: The disruptive queer power of Chaucer's Pardoner. Dalhousie Review, 82(1), 55-73.

\section{$\underline{A U T H O R ' S B I O}$}

Mohamed Karim Dhouib is an assistant professor of English literature at the Faculty of Arts and Humanities of Sousse, Tunisia. His main research interests are premodern and early modern literature and culture, modern literary theories, and medievalism in modern literature, cultutre and cinema 